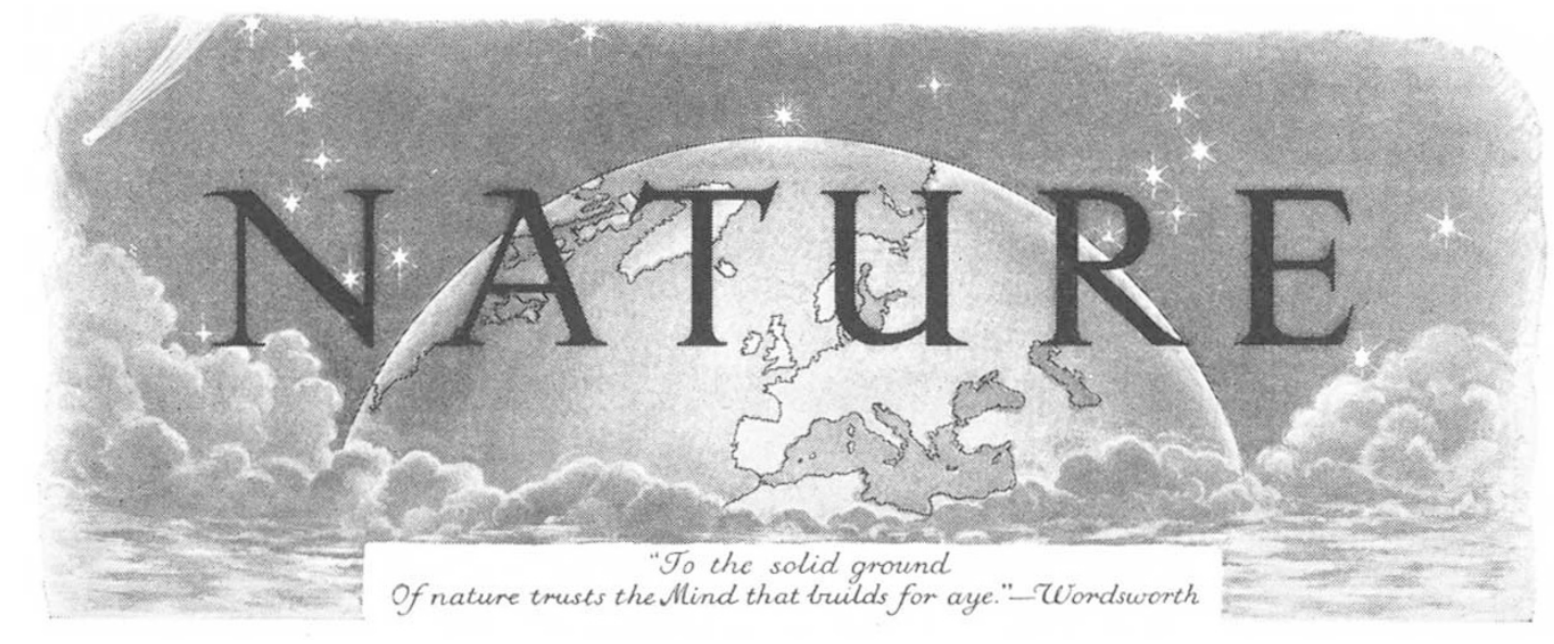

Vol. 146

SATURDAY, JULY 6, 1940

No. 3688

\title{
SCIENTIFIC METHOD IN PROPAGANDA
}

$\mathrm{T}$ 'HE word 'propaganda' is defined in the Oxford Dictionary as "an organized scheme for propagation of a doctrine or practice" ; unfortunately it has acquired a bad, and recently an even sinister, meaning. There are few things from which the scientific worker reacts more instinctively than propaganda. Indeed, his wholesome and genuine prejudice against the word has sometimes led to less than justice being done to the work and abilities of those of his colleagues who have undertaken the task of expounding or interpreting to the world the results of scientific work and their significance for human welfare. There are spheres in which the essential task of education is not readily distinguished from propaganda, and propaganda itself has its uses as well as its abuses. Even societies which exist primarily for research and inquiry may fail of their purpose if they neglect to bring to the notice of the public whatever results have been obtained.

Prejudices which refuse to recognize the right use of an instrument may have consequences as untoward as those which condone abuse, and scientific workers cannot be entirely absolved from responsibility for the consequences of neglect of the important task of exposition. It is not enough for the Government to make even full use of the service of scientific men in the evolution or execution of a policy. Co-operation of the public is also involved to the extent that it demands an intelligent understanding of the policy, and for this an immense campaign of education is essential.

In their own particular studies, scientific workers have as yet given nothing like the attention to this question that is desirable on general grounds, or, in certain fields such as food supply, that is now essential for the development of our war effort. Some aspects of this work may fairly be regarded as falling within the field of the Ministry of Information, but seientific workers are not entitled to criticize the Ministry unreservedly for shortcomings unless they have made their own contribution, or at least put forward constructive proposals. The dissemination and use of information, as much as the acquisition of information, require scientific study and the application of scientific methods.

This is not a matter which can be left entirely to information services. Their special function is the locating of information and its handling in the most efficient form. Only to a limited and technical extent are they concerned with the form in which it is presented or the use to be made of it. The educational aspect lies almost entirely outside their scope. There are features in the present situation, however, which demand the attention and co-operation of scientific workers.

The question of food supply and policy is only one, though probably the most prominent, of the matters in which inadequate use has been made of 
the services of scientific workers, and insufficient guidance has perhaps been given by them. Nor is it alone in being essential for the efficient prosecution of our war effort. Lord Chatfield's statement early in the year regarding the co-ordination of the scientific research carried out by the special departments of the Fighting Services and of the Ministry of Supply only partly dispelled misgiving as to the use being made of scientific services in the immediate task of national defence. In many other wide fields similar concern may be felt with even more reason. The recent report of the Industrial Health Research Board of the Medical Research Council on industrial health in war emphasized the need for applying knowledge already gained, rather than for fresh researches, and stressed the need for development of the work arising from the Health of Munition Workers Committee of 1915-17 and the Industrial Fatigue Research Board established in 1918. The report of the Barlow Commission on the distribution of the industrial population of Great Britain and the various inquiries into the success or failure of evacuation schemes provide other examples of the way in which more effective use might be made of existing scientific knowledge in the development of the national welfare, apart from the extension of that knowledge.

Scientific workers have yet to realize that they have a very large responsibility for seeing that much more adequate use is made of the knowledge which they have made available for the community. They must assist much more wholeheartedly in the interpretation of those results to the community, whether to the administrator or to the general public, in order to secure their integration into the general policy and practice of the community. The new Division for the Social and International Relations of Science of the British Association, in the various inquiries it has set going, has already made progress in this field, but much more is required. Men of science should recognize that concern with the social consequences of the application of their discoveries involves attention to the way in which these discoveries are presented to the public, in order to secure as favourable an opportunity as possible for the use of new knowledge for society's weal rather than its woe.

Interpretation or presentation in this sense is inevitably linked up with the question of education, and of securing that the education of every citizen includes at least enough teaching of general science on broad lines to fit him or her to take a place in this world of applied science and to appreciate the scientific outlook. It involves also the use of what may be called rational propaganda-the propagation by reasoned argument of the knowledge and experience and standards of conduct upon which the future of the race, if not of civilization, depends.

Significantly enough, we have come to realize, as was done some twenty-five years ago, that the successful prosecution of the War demands adequate attention to rational propaganda, not merely within our own boundaries but at least in neutral countries also. If it is neglected, or this field left entirely to our enemies; difficulties and misunderstandings may arise, engendering friction or hostility, which may react dangerously on the effectiveness of our policy. We can no more rely on the justice of our cause and the integrity of our ideals, unsupported by wise and fair exposition, to maintain the sympathy of neutrals, than the scientific worker can rely on the statement of his results before a meeting of his fellows to secure the appropriate use of his work in the service of some national interest.

The importance of propaganda as an instrument of foreign policy is well shown by Prof. E. H. Carr in one of the Oxford Pamphlets on World Affairs, in which he not only points out why democratic Governments find it necessary to control and organize opinion if they are not to be at a serious disadvantage in dealing with the Totalitarian States, but also he demonstrates the necessity for some control by the State, however discreetly veiled, over the instruments of propaganda, if the public good is to be served and the community to survive. Even in time of peace, no Government can afford to leave publicity and propaganda in the unguided hands of private interests.

Much of the interest for scientific workers of Prof. Carr's pamphlet is derived from its analysis of the limits and checks on propaganda as well as of its dangers. The tendency of education, itself an instrument of propaganda, whether rational or not, to promote a spirit of independent inquiry, is one of the strongest defences against its wrong use. Further, the more rational the methods by which propaganda is conducted and the more it is in line with the rights and interests not of a section, or class or nation, but of the world community, the more likely it is to be effective.

What has to be recognized is that, although propaganda is an instrument which can be used 
wisely as well as unwisely, and has its proper place in the maintenance and advancement of order and culture, it is not a scientific inquiry into truth; a balanced exposition of the evidence for or against his thesis cannot fairly be expected from the propagandist. On this ground alone, it is important that institutions such as Political and Economic Planning or the Royal Institute of International Affairs at Chatham House, which have acquired a deserved reputation for the unprejudiced investigation of social, economic and international matters, and the balanced and unprejudiced presentation and interpretation of their findings to the public, should continue their work and be supported by all those concerned in advancing the standard of education and knowledge in the community; although we may regret, perhaps unjustifiably, the closer association of Chatham House with the Foreign Office, as likely to endanger the reputation of the Institute for the impartial examination of such matters. At least it may be hoped that the criticism at present finding expression as to the mode of exposition of Allied policy and aims in the world generally, or the elaboration and execution of domestic policy in Great Britain, may remind the powers that be that scientific workers recognize responsibilities in such fields which they are eager to discharge.

\section{THE SOCIOLOGY OF PLANNING}

Man and Society in an Age of Reconstruciion Studies in Modern Social Structure. By Karl Mannheim. With a Bibliographical Guide to the Study of "Modern Society". Translated from the German by Edward Shils. Pp. xxii +469 . (London: Kegan Paul and Co., Ltd., 1940.) 16s. 6d. net.

DROF. MANNHEIM'S book, we may prophesy, is likely to become the planners' bible, for nowhere else can one find such a complete, up-to-date and well-reasoned analysis of the inevitability of planning, good and bad, and of its techniques. It is, however, more than this rather irreverent comparison would suggest. It is a compendium of modern sociological fact and theory, abundantly documented, woven round the central theme of the planned world's dawning.

Prof. Mannheim was one of the leading sociologists in Germany. With the advent of the Nazi regime, however, he came to Great Britain, and has since been teaching at the London School of Economics. The present volume is a revised and much enlarged edition of an earlier German work published in Holland five years ago. This, as Dr. Mannheim says in his preface, was written when he was "completely under the influence of experiences bred by the disintegrating tendencies of liberal society". He saw how, under certain conditions; the planlessness of the liberal order turned into anarchy. Since then, however, he has been living "in a country where liberal democracy functions almost undisturbed". This enabled him to free himself from his deep-rooted scepticism as to the vitality of democracy in our age. From one aspect, the present volume has become a study, by no means pessimistic, of how planning and order may be combined with the essentials of democracy and freedom.

The formidable extent of the author's learning and background may be gauged by the fact that no fewer than seventy-two pages are taken up. with what he calls a "purely personal bibliography", itself elaborately arranged under subjects and subheads.

No reviewer can pretend to give an adequate account of this lengthy and tightly packed book ; but a brief summary of the main themes of its six parts will give some idea of its scope.

The first part is a study of the rational and irrational elements in modern social existence. In the mass society of the present day, disastrous tensions develop as a result of the numerous contradictions between the high degree of rationalization in industry and its almost complete absence in politics and ordinary human behaviour. Thus industrial organization becomes a mere façade, behind which irrational force is the ultima ratio, both in internal and in foreign politics.

The second study deals with the role of the élite in society. Nineteenth century democracy was a 'minority democracy', from whose benefits large sections of the population were formally or virtually excluded. Such a society, however, had one advantage; it permitted the formation of an élite which had initiative and could in large measure assume the function of intellectual and cultural leadership. With the rapid transforma- 